\title{
A Study on Biochemical Constituents and Anti-Bacterial Activity in the Bark Extract of Millingtonia hortensis
}

\author{
B. R. Sasidharan ${ }^{1}$, P. Balaji ${ }^{2 *}$, K. R. Ashok ${ }^{2}$ and G. Soundarya ${ }^{3}$ \\ ${ }^{1}$ Forest College and Research Institute, Mettupalayam, India \\ ${ }^{2}$ Department of ARM, TNAU, Coimbatore- 641 003, India \\ ${ }^{3}$ CARDS, TNAU, Coimbatore- 641 003, India \\ *Corresponding author
}

\begin{abstract}
A B S T R A C T
Millingtonia hortensis Linn. (Bignoniaceae) commonly known as Cork tree, Akash neem, Neem chameli. It is an important medicinal plant in Southern Asia ranging from India, Burma, Thailand and Southern China, cultivated in most parts of India in gardens and avenues. It can grow up to 25 meter tall. Flowers have very rich and pleasant scent, used in the treatment of asthma, sinusitis, cholagogue, tonic and in rituals. The stem bark is used traditionally as mainly lung tonic, antiasthmatic and antimicrobial properties. Leaves and roots of cork tree used as antiasthmatic and antimicrobial activity. Fruit is very long and narrow, pointed at both ends and contains thin, flat seeds. Trees do not seed very easily in India. The plant has antifungal, antibacterial, larvicidal, antioxidant, antiproliferative, antimutagenic, antihelmintic and hepatoprotective activities. The study was carried out to find the biochemical constituents and anti-bacterial activities of the bark extract of Millingtonia hortensis. The objectives of the study were to analyse the chemical constituents of the bark and to analyze the anti-bacterial activity of the bark of Millingtonia hortensis. In this study, an experiment was conducted to study the biochemical constituents of the bark, the extract was give for GCMS test to SITRA (South Indian Textile Research Association). The results reveals that the bark have four compounds which are all mainly used in medicinal propose. The anti-bacterial activity of the bark of Millingtonia hortensis is studied through laboratory Bacillus subtilis.
\end{abstract}

\section{Introduction}

Millingtonia hortensis Linn. F is an important medicinal plant in Southern Asia, ranging from India, Burma, Thailand and Southern China. A very tall tree, Flowers have very rich \& pleasant scent. It is a drought resistant tree. The Biological name of Millingtonia hortensis belonging to the family of
Bignoniaceae. Propagation by Seeds, suckers. Longevity is Perennial. It is a tall deciduous tree. It grows up to 25 meter.

The leaves are pinnately compound. Long leaves bear two or three widely spaced pinnae, each with 5-7 smooth leaflets, oval, pointed and slightly round-toothed, 1-3 inches long. 
Sometimes the lower pinnae are again divided and bear one pair of three leaved pinnae, 1-2 pairs of leaflets and one leaflet at the end. Flowers in corymbosepanicles, long tubular, silvery-white and delightfully fragrant. It requires full sunlight for its growth. Stem and roots of the Cork tree have great medicinal value. Its dried flower is a good lung tonic. It is also used in the cough diseases. Its flowers are used in the rituals. Its bark is used to produce yellow dye.

Extract of the leaves of Millingtonia hortensis has good antimicrobial activity. Trees $8-25 \mathrm{~m}$ tall. Leaves 40-100 cm; Inflorescences cymose-paniculate. It is a drought resistant, tall deciduous tree, grows at an altitude of $500-1200 \mathrm{~m}$. Largely seen in tropical forest with an average altitude of $0-922 \mathrm{~m}$. The tree grows well in all types of soil with variable climate. The propagation of the tree is carried through seed and suckers.

Millingtonia hortensis and its
pharmacological activity

\section{Antifungal activity}

Sharma et al., (2007) was described the Antifungal activities of different extracts of Millingtonia hortensis were investigated against various fungal pathogens. Methanol extract was found to have stronger activity than fluconazole against yeast like fungi: 4 fold against Candida krusei with $4 \mu \mathrm{g} / \mathrm{ml}$ minimal inhibitory concentration and 2 fold (MIC- $2 \mu \mathrm{g} / \mathrm{ml}$ ) against Sacharomyces cerevisiae, though it showed the same activity as fluconazole against Candidaglabrata.

Aqueous extract also exhibited 4 fold stronger activity against Candida krusei (MIC- 4 $\mu \mathrm{g} / \mathrm{ml}$ ) and 4 fold (MIC; $2 \mu \mathrm{g} / \mathrm{ml}$ ) against Sacharomyces cerevisiae. Chloroform and ethyl acetate extract showed lower activities against all fungal pathogens except for
Candida krusei, compared with the standard. Against the filamentous fungus, Trichosporon cutaneum, all extracts showed less activity than the standard.

\section{Larvicidal activity}

R. Kaushik et al., (2008) was studied Millingtonia hortensis L. (Family: Bignoniaceae) a plant commonly known as 'Akas neem' and also as the 'Indian cork tree" was first reported which reveals the mosquito larvicidal property of M.hortensis. R. Kaushik el al (2009) was Screened 11 plant species of local flora against the IV instar larvae of Aedes aegypti (Diptera: Culicidae).

\section{Antimicrobial activity}

A.Jetty; et al., (2000) was described the Polar extracts of the leaves of Millingtonia hortensis showed good antimicrobial activity. Twenty different bacterial strains and two yeast cultures were used. The aqueous alcohol extract showed good activity against all microbes tested, particularly Escherichia coli and Salmonella typhimurium, both Gramnegative bacteria, with MIC values of 6.25 $\mu \mathrm{g} / \mathrm{ml}$. The activity is compared with known antibiotics such as gentamycin and nystatin.

\section{Mutagenicity and antimutagenicity}

Malyn Chulasiri et al., (2006) was studied the mutagenicity and antimutagenicity of hispidulin and hortensin, the flavonoids from Millingtonia hortensis L. (Bignoniaceae), were performed using the liquid preincubation method of the Salmonella/ microsome test.

At the highest dose tested, $100 \mathrm{~g} /$ plate, both compounds showed no mutagenicity and no cytotoxicity toward $S$. typhimurium strains TA98 and TA100 either in the presence or absence of S9 mix. 
However, these substances were antimutagens toward 2-aminoanthracene, aflatoxin Bl (in TA98), and dimethylnitrosamine (in TA100); but neither substance inhibited the direct mutagenic activity of 2-(2-furyl)-3-(5- nitro2-furyl) acrylamide nor that of sodium azide in strains TA98 and TA100, respectively.

\section{Antiproliferation activity}

Siwapong Tansuwanwong et al., (2009) was described the Millingtonia hortensis is a medicinal plant widely used in many Asian countries. An aqueous crude extract of this plant has been shown the apoptosis induction on RKO colon cancer cells.

However, its mechanism remains unknown. To learn more about this plant extract, we partially purified the crude extract using Sephadex LH-20 and three aqueous fractions were collected. Each fraction was investigated for cytotoxicity using MTT assay.

The crude petroleumether, benzene, chloroform, methanol and aqueous extracts of stem bark of Millingtonia hortensis were evaluated against Escherichia coli, Pseudomonas aeruginosa, Staphylococcus aureus and Bacillus subtilis using agar disc diffusion method using ampicillin as the standard drug.

Petroleum ether extract exhibits significant Zone of Inhibition (ZI) against Pseudomonas aeruginosa, Staphylococcus aureus and Bacillus subtilis, whereas the benzene, chloroform, methanol and aqueous extracts were completely effective against all the four strains under study as compared to the standard drug.

Millingtonia hortensis Linn is tested against the Human cervical cancer cell line by MTT Assay. Antimicrobial capacity of the extract is evaluated by means of agar diffusion method using 12 strains of microbes.
The extract is found to be a poor cytotoxic and antibacterial agent, however it is found to be an effective antifungal agent.

\section{Materials and Methods}

The experimental material to be present study consisted of bark collection from at Forest college and research institute, Mettupalayam. From this species, the bark was collected from Millingtonia hortensis bark of (approximately five year old tree). The collected bark was chopped, shade dried and coarsely powdered by using electrical blender. The Bark powder was used for experiments.

\section{Solvent extraction}

$5 \mathrm{~g}$ of the coarsely powdered bark was used for the solvent extraction process. The $5 \mathrm{~g}$ powdered bark was filled in the thimble of Soxhlet apparatus using methanol as a solvent. The process of extraction continued for an hour at $55^{\circ} \mathrm{C}$. The solvent extracts collected in airtight containers were preserved in refrigerated condition at $5^{0} \mathrm{C}$ for further use.

The extracted solvent was analysed for its bio chemical constituents through Gas Chromatography Mass Spectrometer (GCMS). The Instrument used was THERMO GC - TRACE ULTRA VER: 5.0, THERMO MS DSQ II. The Column in the equipment was DB 35 - MS CAPILLARY STANDARD NON - POLAR COLUMN and the carrier gas used was Helium (He) and its flow was 1.0 ML/Min.

\section{GC-MS studies: principle of gas chromatography -mass spectrometry}

Gas Chromatography is used to separate volatile compounds in a mixture. The extracted solvent was analysed for its bio chemical constituents through Gas 
Chromatography Mass Spectrometer (GCMS). The GC-MS analysis was carried out using a Thermo GC - Trace Ultra ver: 5.0, Thermo MS DSQ II with $30 \mathrm{~m} \times 0.25 \mathrm{~mm} \times 0.25 \mu \mathrm{m}$ of capillary standard non-popular column. The instrument was set to an initial temperature of $70^{\circ} \mathrm{C}$, and maintained at this temperature for $3 \mathrm{~min}$. At the end of this period the oven temperature was rose up to $260^{\circ} \mathrm{C}$, at the rate of an increase of $6^{\circ} \mathrm{C} / \mathrm{min}$, and maintained for 2 min. Injection port temperature was ensured at $250^{\circ} \mathrm{C}$ and Helium flow rate at $1.0 \mathrm{ml} / \mathrm{min}$. The ionization voltage was $70 \mathrm{eV}$. The samples were injected in split mode as 10:1.
Mass spectral scan range was set at 40-700 $(\mathrm{m} / \mathrm{z})$. The ion source temperature was maintained at $220^{\circ} \mathrm{C}$ and Interface temperature was at $240^{\circ} \mathrm{C}$. The MS start time was $0.00 \mathrm{~min}$, and end time was $40.51 \mathrm{~min}$. Interpretation on mass spectrum of GC-MS was done using the database of the South India Textile Research Association (SITRA). The mass spectrum of the unknown component was compared with the spectrum of the known components stored in the SITRA library. The name, molecular weight and structure of the components of the test materials were confirmed (Fig. 1).

Fig.1 GC-MS studies: principle of gas chromatography -mass spectrometry

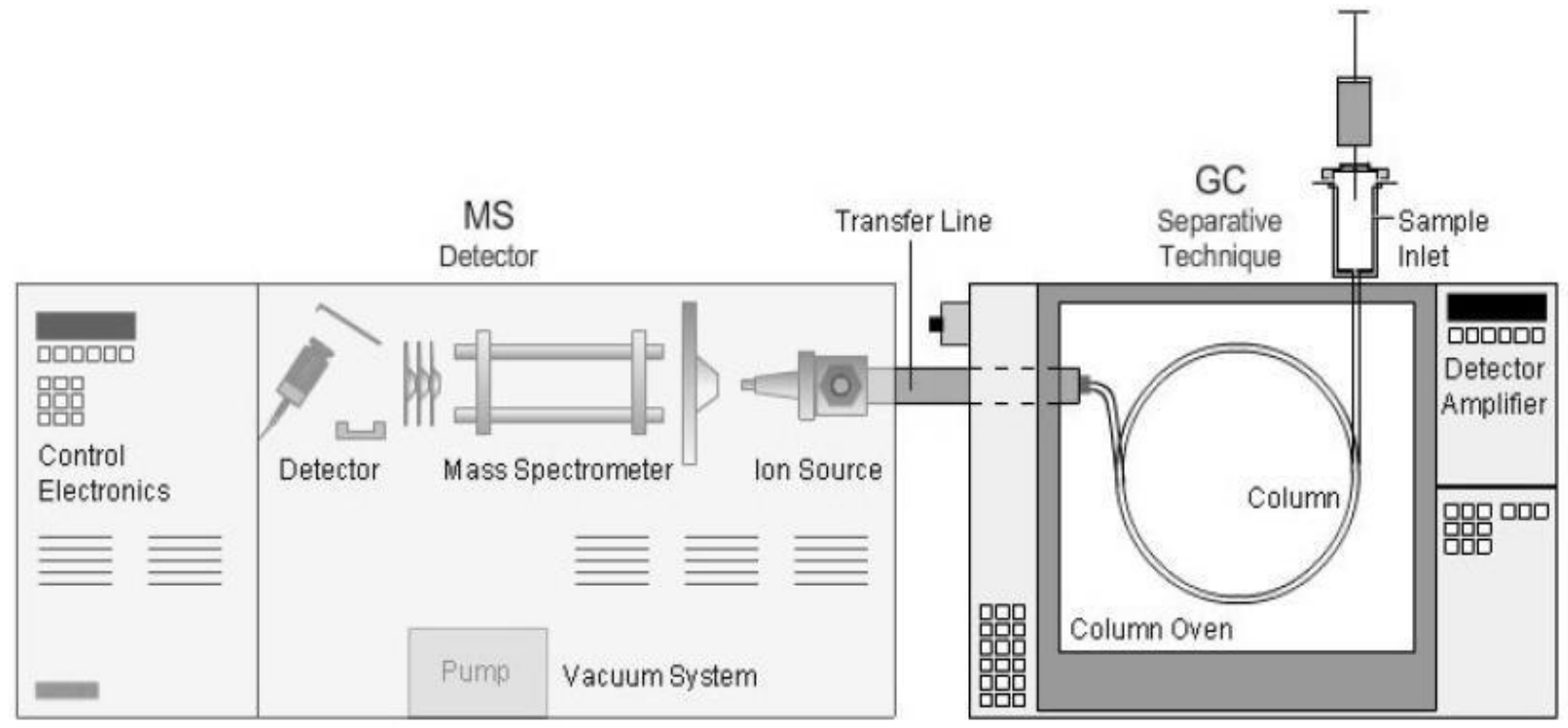

\section{Results and Discussion}

The GC-MS analysis led to the identification of 4 compounds from the Gas Chromatography fractions of the methanol extract of Millingtonia hortensis. The active principles with their retention time (RT), molecular formula and molecular weight (MW) in the methanol extract are presented in Table 1.

The Figure 2 to 4 depicts the peak of the chemical constituents present in the methanol extract.

\section{Anti-bacterial activity}

Antibacterial evaluation studies revealed that the extracts under investigation were found to be completely effective against bacteria employed, the gram positive bacteria, Bacillus subtilis. It showed the presence of zone of inhibition for about $0.2 \mathrm{~mm}$ against Bacillus subtilis. 


\section{Bicyclo [4.1.0] heptanes, 7-pentyl}

From the GC-MS it was interpreted the peak around 166 belongs to Bicyclo [4.1.0] heptanes,7-pentyl which is found at retention time of 9.68. This compound is proved as versatile and also conservation material. It is to be used on wall paintings, plaster, ceramics, paper, textiles and metals.

\section{Dl-alpha-tocopherol}

The peak around 430 belongs to Dl-alphatocopherol which is found at retention time of 10.66. This compound is said to be a source of vitamin $\mathrm{E}$ for the production of tablets.

\section{Octadecanoic acid, butyl ester}

The peak around 340 belongs to Octadecanoic acid, butyl ester compound found at retention time of 10.66. This compound is said to be used in production of hormone that regulate a variety of functions including blood pressure, blood clotting and immune response.

\section{Hentriacontane}

The peak around 436 belongs to Hentriacontane found at retention time of 28.98. This compound is used for Slows down the growth of Mycobacterium tuberculosis, used in the treatment of tuberculosis.

Table.1 Components identified in the bark of Millingtonia hortensis

\begin{tabular}{|l|l|c|c|c|}
\hline NO. & Compound Name & $\begin{array}{c}\text { Molecular } \\
\text { Formula }\end{array}$ & $\begin{array}{c}\text { Molecular } \\
\text { Weight }\end{array}$ & RT \\
\hline $\mathbf{1}$ & Bicyclo[4.1.0]heptanes,7-pentyl & $\mathrm{C}_{12} \mathrm{H}_{22}$ & 166 & 9.68 \\
\hline $\mathbf{2}$ & Dl-alpha -tocopherol & $\mathrm{C}_{29} \mathrm{H}_{50} \mathrm{O}_{2}$ & 430 & 10.66 \\
\hline $\mathbf{3}$ & Octadecanoicacid, butyl ester & $\mathrm{C}_{22} \mathrm{H}_{44} \mathrm{O}_{2}$ & 340 & 10.66 \\
\hline $\mathbf{4}$ & Hentriacontane & $\mathrm{C}_{31} \mathrm{H}_{64}$ & 436 & 28.98 \\
\hline
\end{tabular}

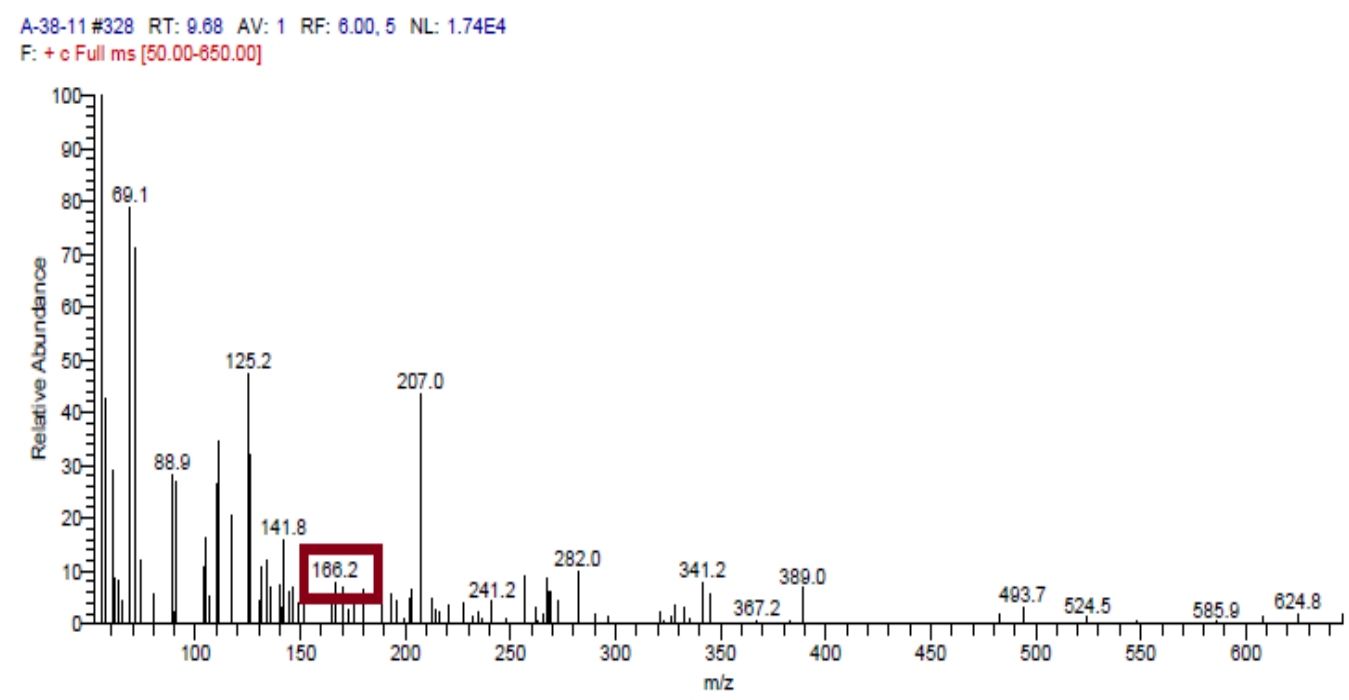

Figure.2 GC-MS Peak at which Bicyclo [4.1.0] heptanes,7-pentyl was detected 


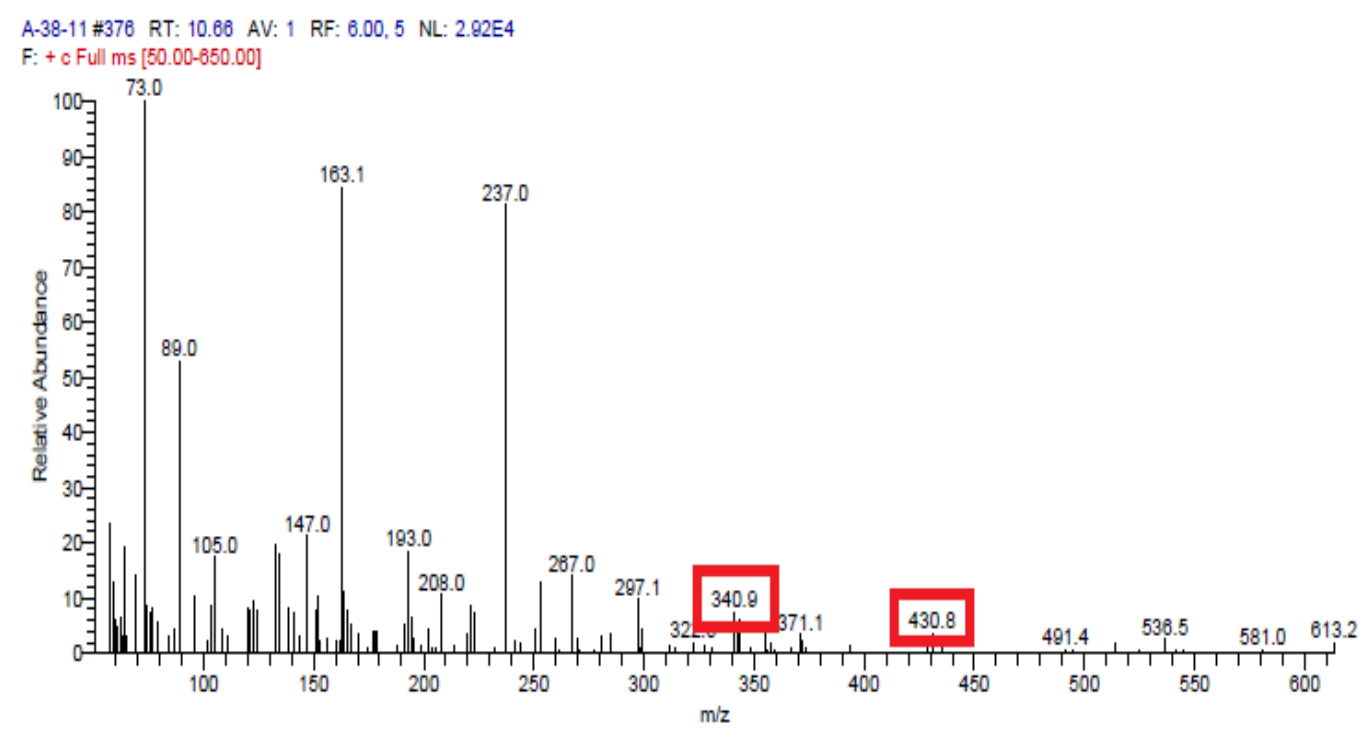

Figure.3 GC-MS Peak at which Octadecanoicacid, butylester,

Dl-alpha-tocopherol were detected

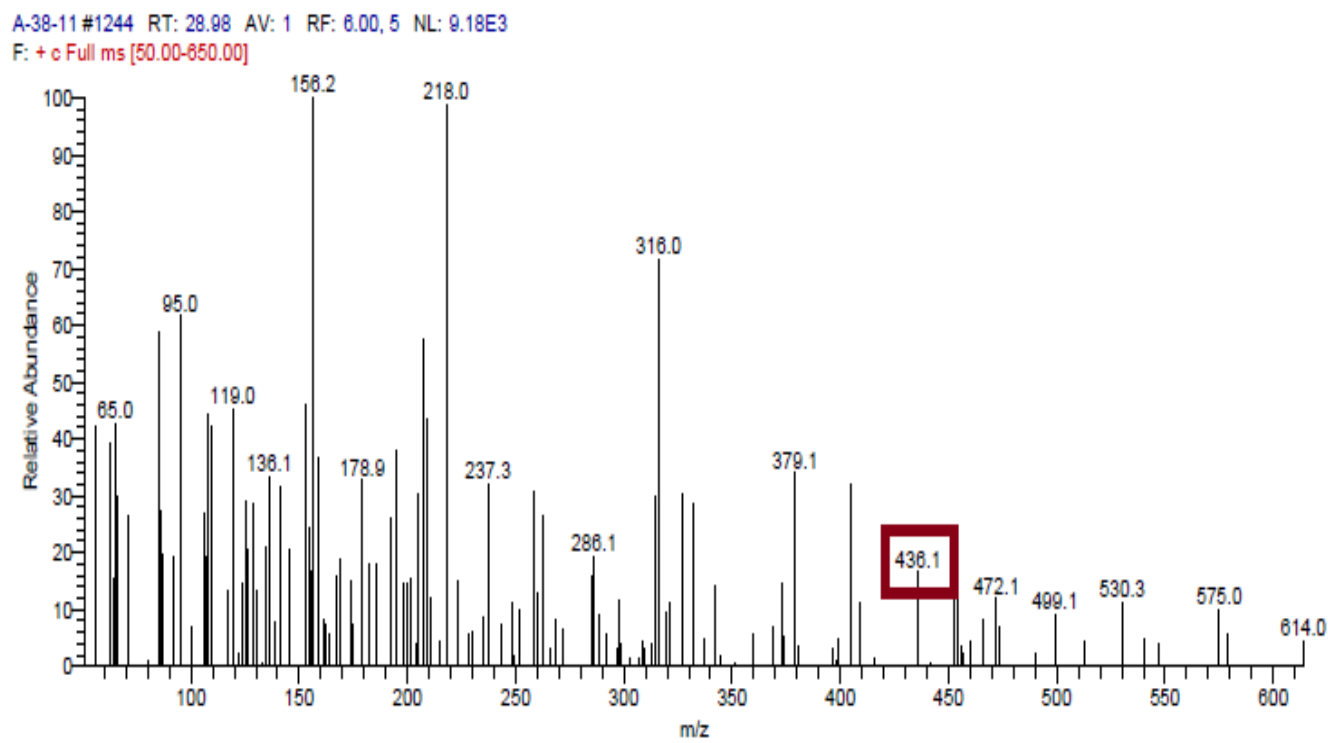

Figure.4 GC-MS Peak at which Hentriacontane was detected

The study on chemical constitution of Millingtonia hortensis bark showed that it have many phyto chemical properties and medicinal properties that are useful for Human being. The chemicals are used for conservation. Millingtonia hortensis L.is a potential Medicinal source with good medicinal components so it can be used in medicinal purpose. This study may give information to the possible production of useful chemical components from Millingtonia hortensisin a large scale. The presents of Anti-bacterial activity showed that the bark can be used for bacterial infections.

\section{References}

Amzad Hossain M., Zhari I, AtiqurR , Sun CK, 2008. Chemical composition and antifungal properties of essential oils and crude extracts of Orthosiphon stamineus Benth 
.Ind. Crop. Prod, 27: 328- 334.

Anonymous. (1999). Preliminary phytochemical and antimicrobial investigations on Meliadubia Bark: Department of Pharmaceutical Chemistry, J.S.S. College of Pharmacy, Rocklands, P.B. No.20, Ootacamund - 643 001, Tamilnadu, India. Ancient Science of Life, 19(1-2), 1-6.

Banskota A H, Tezuka Y, Tran QL, KadotaS , 2003. Chemical constituents and biological activities of Vietnamese medicinal plants“. Curr.Top. Med. Chem, 3: 227-248,

British Pharmacopoeia, Pharmaceutical Press, London, 796, (1953).

Chanthuru A, Prabhu, MM, Aysha OS and Karthik R. (2014). Evaluation of leaf and root extracts of Meliadubia L. against larvae of Culex quinquefasciatus and five important human pathogens. Biosciences Biotechnology Research Asia, 11 (1), 207210.

Chatterjee A, Pakrashi SC, 1997.The Treatise on Indian Medicinal Plants, National Institute of Science Communication (CSIR) New Delhi, India, Vol. 3, 108.

De Silva LB Stöcklin W, Geissman TA. (1969). The isolation of salannin from Meliadubia. Phytochemistry, 8 (9), 1817-181

De Silva, L.B., Stocklin, W. Geissman, T.A., Phytochemistry, 8, 1817 - 1819, (1969).

Dictionary of Indian Medicinal Plants, Central Institute of Medicinal Aromatic Plants, Lucknow, 292, (1992).

Ghani A, 2003. Medicinal Plants of Bangladesh, second edition, Asiatic Society of Bangladesh, Dhaka-1000: 69-70.

Harborne, J.B., Phytochemical Methods, Jackmann Hall, London, 1-34, (1973).

Irobi, O.N., Moo-Young, M. and Anderson, W.A., Int. J. Pharmacog., 34(2), 87- 90, (1996).
Kumar VS, Sharma A, Tiwari R, Sushil K, MurrayaKoenigii 1999-a review, On Medicinal Resources of Rutaceous Plants And Development To Pharmaceutical Chemistry, Natural Med. 54: 117-122.

Jetty; D. S. Iyengar (2000) Antimicrobial Activity of Millingtonia Hortensis Leaf Extract Pharmaceutical Biology, Volume 38, Issue 2 April 2000 , pages $157-160$

Karthikeyan J, Kamalanathan MN, George T, Elangovan V.(2014). Larvicidal and antibacterial efficacy of green synthesized silver nanoparticles using meliadubia. International Journal of Pharmacy and Pharmaceutical Sciences, 6 (7), 395-399.

M Sharma, S Puri, PD Sharma (2007) Antifungal activity of Millingtonia hortensis Indian Journal of Pharmaceutical Sciences Volume 69, Issue: 4 Page: 599-601.

Malyn Chulasiri, Nuntawan Bunyapraphatsara, Primchanien Moongkarndi (2006) Mutagenicity and antimutagenicity of hispidulin and hortensin, the flavonoids from Millingtonia hortensis L. Environmental and Molecular Mutagenesis Volume 20 Issue 4, Pages 307 - 31210.

R. Kaushik \& P. Saini (2008) Larvicidal activity of leaf extract of Millingtonia hortensis (Family: Bignoniaceae) against Anopheles stephensi, Culex quinquefasciatus and Aedes aegypti. Vector Borne Dis 45, pp. 66-69 8.

Siwapong Tansuwanwong1 , Hiroyuki Yamamoto2, Kohzoh Imai2 and Usanee Vinitketkumnuen (2008) Antiproliferation and Apoptosis on RKO Colon Cancer by Millingtonia hortensis Plant Foods for Human Nutrition (Formerly Qualitas Plantarum) Volume 64, Number 1 page 1117.

\section{How to cite this article:}

Sasidharan, B. R., P. Balaji, K. R. Ashok and Soundarya, G. 2020. A Study on Biochemical Constituents and Anti-Bacterial Activity in the Bark Extract of Millingtonia hortensis. Int.J.Curr.Microbiol.App.Sci. 9(05): 2436-2442. doi: https://doi.org/10.20546/ijcmas.2020.905.279 